Egyptian Journal of Rabbit Science, 25(1): 1 - 19(2014)

\title{
IMPACT OF GELATIN AND $\alpha$-CHYMOTRYPSIN SUPPLEMENTATION IN RABBIT SEMEN EXTENDER ON KINDLING RATE AND LITTER TRAITS
}

\author{
M. E. El-Speiy and A. M. El-Hanoun \\ Animal Production Research Institute, Agriculture Research Center, Egypt. \\ mohamedelspeiy@yahoo.com \& alielhanoun@yahoo.com
}

The present work was carried out to study the effect of addition gelatin and $\alpha$-chymotrypsin to semen rabbit extender on semen quality and litter traits during incubation at 37oC for up to 4 hours and storage at $5 \circ C$ for up to 72 hours of V.line rabbits. Twenty sexually mature bucks and eighty multiparous does of V.Line rabbits in various parities were used. A base extender was prepared (Tris-citric acidglucose) used a basal buffer. The basal extender was divided into five portions and treated as following: (1) Tris-based extender (control), (2) Tris-based extender + 1gm gelatin/100ml, (3) Tris-based extender $+1 \mathrm{gm}$ gelatin/100ml $+100 m g$-chymotrypsin/100ml (4) Tris-based extender +1 gm gelatin/100ml $+200 m g$-chymotrypsin/100ml, and (5) Tris-based extender $+1 \mathrm{gm}$ gelatin/100ml $+400 \mathrm{mg} \alpha$ chymotrypsin/100ml. The concentrations of total free amino acids were determined in the five portions extenders. Semen was collected by artificial vagina twice weekly for ten consecutive weeks. Semen ejaculates were evaluated microscopically and only the ejaculates with advanced sperm motility $\geq 70 \%$ were pooled and used. Semen from different bucks was pooled and divided into five equal portions and each portion was diluted with one of the previous prepared extenders. The final dilution of all groups extender was 1 semen: 4 extender. Thereafter, each extender semen portion was divided into two sub-portions; the first portion was incubated at $37 \circ \mathrm{C}$ for 0,2 and 4 hours, while the second portion was stored at $5{ }^{\circ} \mathrm{C}$ for 24,48 , and 72 hours. Fresh semen samples were also collected and treated as described above and used immediately for artificial insemination.

The obtained results indicated that the total free amino acids for treated extender groups were higher $(P<0.05)$ compared with those for control group. Extender supplied with the high level of $\alpha$ chemotrypsin (400mg) showed the highest increase $(P<0.05)$ of all free amino acids with the lowest $(P<0.05)$ content of ammonia. Irrespective of cold temperature $(5 \circ \mathrm{C})$ and incubation time $(37 o \mathrm{C})$ added with gelatin and $\alpha$-chemotrypsin to Tris-buffer extender 
increased $(P<0.05)$ percentages of advanced sperm motility and decreased abnormality and dead sperm. The percentages of advanced sperm motility decreased $(P<0.05)$, while sperm abnormal and dead spermatozoa increased $(P<0.05)$ by elevated storage temperature or incubation time. Concentrations of ALT and AST in seminal plasma were reduced $(P<0.05)$ in the treated groups. However, the activated of ALT and AST enzymes activities increased $(P<0.05)$ by either the elevated storage temperature or by incubation time. Values of thiobarbituric acid-reactive substances (TBARS) and superoxide dismutase $(S O D)$ decreased $(P<0.05)$ in treated samples compared with the control group. However, the levels of TBARS and SOD increased $(P<0.05)$ and glutathione $(G S H)$ decreased $(P<0.05)$ by advancement of incubation time or by storage temperature. Kindling rate of females artificially inseminated with semen extender supplemented with different levels of $\alpha$-chemotrypsin and gelatin were improved $(P<0.05)$ compared with the control group. In addition, the total and live litter size at birth, litter size at weaning, bunny weight at birth and bunny weight at 28 days were increased $(P<0.05)$ in treated groups than the control. However, there found no differences between 200 and $400 \mathrm{mg} \alpha$-chymotrypsin on these trait.

In conclusion, rabbit semen extender supplementing with gelatin and $\alpha$-chemotrypsin not only enhanced the semen quality and extended its storagability but it also improved its subsequent impacts on the reproductive performance.

Key words: Rabbits, gelatin, $\alpha$-chymotrypsin, semen extender, litter traits

In several mammalian species, it has been suggested that some of the amino acids that are detected in seminal plasma enhanced sperm metabolism and its sperm motility (Gassner and Hopwood, 1952), viability and acrosome reaction (Roth et al., 1988). Ibrahim and Boldizsár (1981) showed that high amounts of total free amino acids in buck semen are important for the semen quality and fertility rate.

The addition of amino acids to extender improved post-thawing sperm motility, viability, acrosome and membrane integrity in goat (Ali Al Ahmad et al., 2008). Numerous studies showed that, supplementation of dipeptides alanin-glutamic and glycine-glutamic can play an important role in decreasing ammonia toxicity for the living cells, which lead to a progressive loss in sperm motility (Kim and Kim, 1998) maturation and fertilization of porcine oocytes (Ka et al.,1997). Moreover, it is well known that, mammalian sperm contains a high concentration of polyunsaturated fatty 
acids (PUFA) in their membranes and they lack a significant cytoplasmic component containing antioxidants. Therefore, sperm cells are highly susceptible to lipid peroxidation (LPO) by free radicals such as O2 and $\mathrm{H} 2 \mathrm{O} 2$ (Gadella et al., 2001), which lead to the structural damage of sperm membranes during freezing-thawing process (Sinha et al., 1996). Based on this information, the composition of extender and suitable cryoprotectants seem to play an important role for successful semen cryopreservation (Curry et al., 1994).

Kutteh (1996) showed that antisperm-antibody (ASA) found systemically in seminal plasma. Antibodies in the blood and lymph belong predominantly to the immunoglobulin $\mathrm{G}$ (IgG) isotype, while those found in external secretions are predominantly of the $\operatorname{IgA}$ isotype (Mazumdar and Levine, 1998). Bronson et al., (1987) showing that treating sperm with autoantibodies by an ASA protease was able to overcome the block to mucus penetration. Bollendorf et al., (1994) also found that treating sperm bound with autoantibodies with the protein digestive enzyme $\alpha$-chymotrypsin followed by an intra uterine injection (IUI) was more effective in achieving pregnancies than IUI with sperm ejaculated with albumin.

Gelatin addition to semen extender was reported by several studies. Lòpez-Gatius et al. (2005) mentioned that the use of gelatin may exert beneficial effects through; (1) avoiding sperm cell sedimentation, consequently reducing changes in medium conditions or composition and (2) immobilizing spermatozoa, reducing the metabolic demands of motion, while preserving their fertilization potential. Regarding rabbit, the addition of gelatin $(1 \mathrm{~g} / 100 \mathrm{ml}$ extender) had a positive effect on the viability and acrosomal integrity of spermatozoa stored for 72 h (Lòpez-Gatius et al., 2005). Zaghloul (2009) showed that there was a positive effect of adding gelatin on the viability and integrity of rabbit spermatozoa after short-term storage.

Therefore, the present study aimed to define the effects of $\alpha$ chymotrypsin and gelatin supplementation to the extender on free amino acids in rabbit semen quality, release of antioxidants, kindling rate, fertility and litter traits.

\section{MATERIALS AND METHODS}

The present study was carried out at El-Sabahia Poultry Research Station, Alexandria Governorate, belonging to Animal Production Research Institute, Agricultural Research Center, Egypt.

\section{Animals, Semen Collection and Processing}

Twenty sexually mature bucks and eighty multiparous does in three sequence parities of V-line (VL) rabbits were used. All rabbits were housed in a 
naturally ventilated building and kept in individual wire galvanized cages $(60 \times$ $55 \times 40 \mathrm{~cm}$ ) equipped with an internal nest-box. Rabbits were fed ad libitum with a commercial pelleted diet containing $18 \% \mathrm{CP}, 13.3 \% \mathrm{CF}$ and $2670 \mathrm{kcal}$ $\mathrm{DE} / \mathrm{kg}$ diet. Clean tape water was provided as free choice. All the experimental animals were healthy and clinically free from internal and external parasites and kept under the same managerial and hygienic conditions.

A base extender was prepared to use in this experiment consisting of $3.028 \mathrm{~g}$ Tris (hydroxymethyl-aminomethane, Germany), $1.5 \mathrm{~g}$ citric acid anhydrous, $1.25 \mathrm{~g}$ glucose, $500 \mathrm{IU}$ penicillin, 500bug streptomycin sulphate in $100 \mathrm{ml}$ distilled water. The extension was carried out by adding the appropriate volume of the semen slowly to the extender. Extended semen (in tubes) was kept below the level of water in a water bath at all times to avoid fluctuations in semen temperatures. The final extension rate was 1 semen: 4 extender.

The base extender was divided into five portions and treated as following:

Extender 1 - base extender (control) (C),

Extender 2 - base extender+1g gelatin/100ml extender (G0),

Extender 3 - base extender+1g gelatin $+100 \mathrm{mg} \alpha$-chymotrypsin/ 100ml extender (G100),

Extender 4 - base extender+1g gelatin $+200 \mathrm{mg}$ a-chymotrypsin/ 100ml extender (G200),

Extender 5 -base extender $+1 \mathrm{~g}$ gelatin $+400 \mathrm{mg} \alpha$-chymotrypsin/ $100 \mathrm{ml}$ extender (G400).

Total free amino acids in all extenders were determined according to the method described by Hamilton (1962), while the individual free amino acids were measured using a method described by Spackman et al. (1958) using amino acid analyzer system (Hitachi L-8500, Tokyo, Japan) .Semen was collected by an artificial vagina twice weekly for ten consecutive weeks. Gel plug was removed immediately after collection. Semen ejaculates were individually evaluated microscopically and only ejaculates showing advanced sperm motility $\geq 70 \%$ were pooled and used. Semen from different bucks was pooled and divided into five equal portions and each portion was diluted with one of the above mentioned extenders.

The percentage of motile sperm was estimated by visual examination under low magnification (X100) using a phase-contrast microscope with warm stage. Assessment of abnormal and dead spermatozoa was performed using an eosin-nigrosine blue staining mixture (WHO, 1992).

Each previous extender was divided into two sub-portions, the first portion was incubated at $37{ }^{\circ} \mathrm{C}$ and tested at 0,2 and 4 hours, while the second portion was stored at $5{ }^{\circ} \mathrm{C}$ and tested at 24,48 , and 72 hours post treatment. 


\section{Enzymes and TBARS determinations in diluted seminal plasma}

Samples were analyzed biweekly for the Thiobarbituric acid-reactive substances (TBARS) in the diluted seminal plasma using the method of Tappel and Zalkin (1959). Glutathione (GSH) was determined using commercial glutathione reduced kits according to the method of Beutler et al. (1963). Superoxide dismutase (SOD) activity was assayed according to Misra and Fridovich (1972). Aspartate aminotransferase (AST) and alanine

aminotransferase (ALT) were detected according to Reitman and Frankel (1957).

\section{Rabbit does insemination}

All rabbit does were injected with $20 \mu \mathrm{g}$ gonadotropin-releasing hormone (Gonadoreline, Fertagyl, Intervet Lab, Holand) to induce ovulation immediately before insemination as described by Lòpez and Alvarino (2000). Rabbit does were divided into five equal experimental groups (16 does /extender) and inseminated artificially by semen diluted with 50 x 106 fertile sperm at zero time. The insemination procedure was done as described by Adams (1981). Kindling rate, total number of born live and weaning kids were recorded according to IRRG (2005).

\section{Statistical analysis}

All data were subjected to analysis of variance according to the statistical analysis system described by SAS (2002). The differences among groups means were tested by using Duncan's multiple rang test (Duncan, 1955). Kindling rate results were analyzed by the Chi-square test.

\section{RESULTS AND DISCUSSION}

As shown in Table 1 most amino acids significantly $(\mathrm{P}<0.05)$ increased by the inclusion of gelatin alone or gelatin plus $\alpha$ chemotrypsin. The predominant amino acids in rabbit seminal plasma were therionine, glutamic and leucine. Total free amino acids were 16.35, 42.44, 64.26, 104.14 and $174.12 \mathrm{mg} / 100 \mathrm{ml}$ extended semen for C, G0, G100, G200 and G400, respectively. Similar results are in agreement with that those of Centenaro et al. (2011) who reported that the increase of total free amino acids in extended semen treated with $\alpha$-chemotrypsin may be due to the digestive enzyme activity that can perform proteolysis and hydrolyzes amid bonds in protein and peptides (gelatin). Protein hydrolysates from various sources have been identified as potential antioxidants (Rossini et al., 2007). Centenaro et al. (2011) also noted that the peptide from protein hydrolyses presented free radical scavenging activity. This indicates that the peptides or free amino acids in the hydrolysates have the ability to donate 
Table 1. Effect of gelatin and $\alpha$-chymotrypsin supplementation in rabbit semen extender on free amino acid composition $(\mathbf{L S M} \pm \mathbf{S E M})$

\begin{tabular}{|c|c|c|c|c|c|}
\hline \multirow{2}{*}{ Amino acid } & \multicolumn{5}{|c|}{ Gelatin $(1 \mathrm{~g} / 100 \mathrm{ml})+\alpha$-chymotrypsin level $(\mathrm{mg} / 100 \mathrm{ml})$} \\
\hline & Control & $\mathbf{0}$ & 100 & 200 & 400 \\
\hline Aspartic acid & $0.60 \pm 0.89^{\mathrm{e}}$ & $0.74 \pm 0.96^{\mathrm{d}}$ & $0.98 \pm 0.11^{\mathrm{c}}$ & $1.16 \pm 0.12^{\mathrm{b}}$ & $1.29 \pm 0.12^{\mathrm{a}}$ \\
\hline Threonine & $8.20 \pm 0.11^{\mathrm{d}}$ & $16.16 \pm 0.14^{\mathrm{c}}$ & $16.24 \pm 0.13^{c}$ & $23.84 \pm 0.18^{b}$ & $34.57 \pm 0.25^{\mathrm{a}}$ \\
\hline Serine & $0.14 \pm 0.00^{\mathrm{e}}$ & $0.47 \pm 0.00^{\mathrm{d}}$ & $1.11 \pm 0.00^{c}$ & $1.58 \pm 0.00^{\mathrm{b}}$ & $1.87 \pm 0.01^{\mathrm{a}}$ \\
\hline Glutamic acid & $3.42 \pm 0.14^{\mathrm{d}}$ & $6.58 \pm 0.16^{\mathrm{c}}$ & $8.61 \pm 0.18^{b}$ & $8.24 \pm 0.17^{b}$ & $9.21 \pm 0.19^{\mathrm{a}}$ \\
\hline Proline & $0.66 \pm 0.08^{c}$ & $1.86 \pm 0.11^{\mathrm{b}}$ & $1.96 \pm 0.13^{b}$ & $2.11 \pm 0.12^{\mathrm{a}}$ & $2.15 \pm 0.12^{\mathrm{a}}$ \\
\hline Glycine & $0.14 \pm 0.00^{\mathrm{e}}$ & $0.21 \pm 0.00^{\mathrm{d}}$ & $0.87 \pm 0.00^{\mathrm{c}}$ & $1.12 \pm 0.00^{\mathrm{b}}$ & $1.38 \pm 0.00^{\mathrm{a}}$ \\
\hline Alanine & $0.50 \pm 0.00^{\mathrm{e}}$ & $3.13 \pm 0.11^{\mathrm{d}}$ & $16.24 \pm 0.14^{\mathrm{c}}$ & $28.19 \pm 0.17^{b}$ & $65.87 \pm 2.14^{\mathrm{a}}$ \\
\hline Cystine & $0.54 \pm 0.02^{\mathrm{d}}$ & $4.43 \pm 0.06^{\mathrm{c}}$ & $5.53 \pm 0.08^{c}$ & $19.54 \pm 0.14^{\mathrm{b}}$ & $23.15 \pm 0.16^{\mathrm{a}}$ \\
\hline Valine & $0.45 \pm 0.00^{\mathrm{e}}$ & $1.42 \pm 0.11^{\mathrm{d}}$ & $2.48 \pm 0.13^{c}$ & $4.36 \pm 0.15^{b}$ & $7.14 \pm 0.16^{\mathrm{a}}$ \\
\hline Methionine & $0.61 \pm 0.07^{\mathrm{e}}$ & $1.21 \pm 0.10^{\mathrm{d}}$ & $1.81 \pm 0.12^{\mathrm{c}}$ & $2.02 \pm 0.14^{b}$ & $3.10 \pm 0.17^{\mathrm{a}}$ \\
\hline Isoleucine & $0.30 \pm 0.12^{\mathrm{e}}$ & $1.73 \pm 0.39^{\mathrm{d}}$ & $1.99 \pm 0.47^{\mathrm{c}}$ & $2.41 \pm 0.59^{b}$ & $9.05 \pm 0.78^{\mathrm{a}}$ \\
\hline Leucine & $1.60 \pm 0.06^{\mathrm{e}}$ & $1.85 \pm 0.13^{\mathrm{d}}$ & $2.38 \pm 0.15^{\mathrm{c}}$ & $2.96 \pm 0.15^{\mathrm{b}}$ & $3.22 \pm 0.18^{\mathrm{a}}$ \\
\hline Tyrosine & $0.31 \pm 0.00^{\mathrm{e}}$ & $0.55 \pm 0.00^{\mathrm{d}}$ & $0.86 \pm 0.00^{c}$ & $2.79 \pm 0.071^{\mathrm{b}}$ & $4.50 \pm 0.10^{\mathrm{a}}$ \\
\hline Phenylalanine & $0.94 \pm 0.08^{\mathrm{e}}$ & $0.96 \pm 0.08^{\mathrm{d}}$ & $1.89 \pm 0.12^{\mathrm{c}}$ & $2.07 \pm 0.14^{\mathrm{b}}$ & $2.43 \pm 0.15^{\mathrm{a}}$ \\
\hline Histidine & $0.77 \pm 0.07^{\mathrm{d}}$ & $0.88 \pm 0.07^{\mathrm{c}}$ & $0.92 \pm 0.09^{c}$ & $1.18 \pm 0.10^{\mathrm{b}}$ & $4.51 \pm 0.16^{\mathrm{a}}$ \\
\hline Lysine & 0.00 & 0.00 & 0.00 & 0.00 & 0.00 \\
\hline Arginine & $0.17 \pm 0.00^{\mathrm{e}}$ & $0.26 \pm 0.00^{\mathrm{d}}$ & $0.39 \pm 0.00^{\mathrm{c}}$ & $0.57 \pm 0.00^{\mathrm{b}}$ & $0.68 \pm 0.00^{\mathrm{a}}$ \\
\hline $\begin{array}{l}\text { Total free amino } \\
\text { acids }\end{array}$ & $16.35 \pm 1.79^{\mathrm{e}}$ & $42.44 \pm 2.15^{\mathrm{d}}$ & $64.26 \pm 2.75^{\mathrm{c}}$ & $104.14 \pm 3.3^{b}$ & $174.12 \pm 5.3^{\mathrm{a}}$ \\
\hline Amonia & $2.56 \pm 0.10^{\mathrm{a}}$ & $1.88 \pm 0.08^{\mathrm{b}}$ & $1.56 \pm 0.07^{\mathrm{c}}$ & $1.38 \pm 0.06^{\mathrm{d}}$ & $0.26 \pm 0.00^{\mathrm{e}}$ \\
\hline
\end{tabular}

Means with different superscripts in the same row significantly $(\mathrm{P}<0.05)$ differ, ${ }^{*} \mathrm{n}=25$ samples.

hydrogen atoms to the free radicals, slowing the propagation of lipid peroxidation process as reported by Faithong et al. (2010).

Ammonia decreased $(\mathrm{P}<0.05)$ in semen extended supplied with gelatin and different levels of $\alpha$-chemotrypsin. This in association with results reported by Bilodeau et al.(2009) who demonstrated that the accumulation of ammonia can be reduced in the medium by supplementation with the dipeptides L-alanyl-L-glutamine and L-glycyl-L-glutamine, which can play an important role in motility. The role of $\alpha$-chemotrypsin plays on protein by its conversion into small peptide and free amino acids might parallel. Similar trend were reported by Bilodeau et al. (2009).

Results represented in Tables 2 and 3 that supplementation of gelatin and $\alpha$-chemotrypsin had a significant $(\mathrm{P}<0.05)$ effect on sperm quality. Adding gelatin and $\alpha$-chemotrypsin to Tris-buffer extender significantly $(\mathrm{P}<0.05)$ increased percentages of advanced motility and decreased sperm abnormality $(\mathrm{P}<0.05)$ and dead spermatozoa as compared to the control, regardless of storage temperature or incubation time. Percentages of advanced motility significantly $(\mathrm{P}<0.05)$ decreased while dead spermatozoa and sperm abnormality $(\mathrm{P}<0.05)$ increased by the elevation of storage temperature or incubation time. 
IMPACT OF GELATIN AND $\alpha-$ CHYMOTRYPSIN SUPPLEMENTATION IN RABBITS 7

Table 2. Effect of gelatin and $\alpha$-chemotrypsin supplementation in rabbit semen extender and incubation time at $37^{\circ} \mathrm{C}$ on sperm quality $(\mathbf{L S M}+\mathbf{S E M})$

\begin{tabular}{|c|c|c|c|}
\hline Items & $\begin{array}{l}\text { Advanced } \\
\text { Motility \% }\end{array}$ & $\begin{array}{l}\text { Abnormal } \\
\text { Sperm \% }\end{array}$ & $\begin{array}{c}\text { Dead } \\
\text { Spermatozoa\% }\end{array}$ \\
\hline \multicolumn{4}{|c|}{ Effect of supplementation } \\
\hline$* \mathrm{C}$ & $69.64 \pm 2.22^{b}$ & $23.43 \pm .88^{\mathrm{a}}$ & $18.92 \pm 0.96^{\mathrm{a}}$ \\
\hline G0 & $79.00 \pm 1.24^{\mathrm{a}}$ & $21.00 \pm 0.61^{\mathrm{b}}$ & $15.01 \pm 0.56^{\mathrm{b}}$ \\
\hline G100 & $83.25 \pm 0.80^{\mathrm{a}}$ & $20.34 \mathrm{~b} \pm 0.41^{\mathrm{b}}$ & $13.93 \pm 0.46^{\mathrm{c}}$ \\
\hline G200 & $83.74 \pm 0.84^{\mathrm{a}}$ & $20.18 \pm 0.89^{b}$ & $13.21 \pm 035^{\mathrm{c}}$ \\
\hline G400 & $82.92 \pm 0.78^{\mathrm{a}}$ & $20.24 \pm 0.43^{b}$ & $13.36 \pm 039^{c}$ \\
\hline \multicolumn{4}{|c|}{ Effect of incubation time (h) at $37^{\circ} \mathrm{C}$} \\
\hline 0 & $85.51 \pm 0.70^{\mathrm{a}}$ & $18.25 \pm 0.17^{\mathrm{c}}$ & $11.40 \pm 0.16^{\mathrm{c}}$ \\
\hline 2 & $78.83 \pm 1.13^{\mathrm{b}}$ & $20.88 \pm 0.31^{b}$ & $15.11 \pm 0.41^{\mathrm{b}}$ \\
\hline 4 & $75.37 \pm 1.39^{\mathrm{b}}$ & $23.9 \pm 0.41^{\mathrm{a}}$ & $17.95 \pm 0.51^{\mathrm{a}}$ \\
\hline
\end{tabular}

Table 3. Effect of gelatin and $\alpha$-chemotrypsin supplementation in rabbit semen extender and storage time at $5^{\circ} \mathrm{C}$ on sperm quality $(\mathrm{LSM} \pm \mathrm{SEM})$

\begin{tabular}{|c|c|c|c|}
\hline Items & $\begin{array}{l}\text { Advanced } \\
\text { Motility \% } \\
\end{array}$ & $\begin{array}{l}\text { Abnormal } \\
\text { Sperm \% }\end{array}$ & $\begin{array}{c}\text { Dead } \\
\text { Spermatozoa \% } \\
\end{array}$ \\
\hline \multicolumn{4}{|c|}{ Effect of supplementation } \\
\hline$* \mathrm{C}$ & $56.81 \pm 2.32^{c}$ & $37.10 \pm 0.86^{\mathrm{a}}$ & $29.55 \pm 1.12^{\mathrm{a}}$ \\
\hline G0 & $67.59 \pm 1.53^{\mathrm{b}}$ & $27.32 \pm 0.56^{\mathrm{b}}$ & $22.70 \pm 0.31^{\mathrm{b}}$ \\
\hline G1 & 70.7 & $26.06 \pm 0.47^{b}$ & $20.40 \pm 0.59^{c}$ \\
\hline G2 & 71.6 & 25.1 & $19.36 \pm 0.53^{c}$ \\
\hline G400 & $71.99 \pm 1.02^{\mathrm{a}}$ & 26.5 & $19.96 \pm 0.57^{\mathrm{c}}$ \\
\hline \multicolumn{4}{|c|}{ Effect of storage time (h) at $5^{\circ} \mathrm{C}$} \\
\hline 24 & $76.08 \pm 0.87^{\mathrm{a}}$ & $25.27 \pm 0.49^{c}$ & $17.82 \pm 0.36^{\mathrm{c}}$ \\
\hline 48 & $67.20 \pm 0.86^{\mathrm{b}}$ & $28.64 \pm 0.75^{\mathrm{b}}$ & $22.46 \pm 0.59^{b}$ \\
\hline 72 & $59.97 \pm 1.50^{\mathrm{c}}$ & $31.37 \pm 0.78^{\mathrm{a}}$ & $26.91 \pm 0.75^{\mathrm{a}}$ \\
\hline
\end{tabular}

Means in the same column within category with different superscripts significantly differ $(\mathrm{P} \leq 0.05) .{ }^{*} \mathrm{C}=$ Control, G0= Gelatin, G100= Gelatin $+100 \mathrm{mg} \alpha$-Chemotrypsin, G200= Gelatin + $200 \mathrm{mg} \alpha$-Chemotrypsin, G400= Gelatin $+400 \mathrm{mg} \alpha$-Chemotrypsin (/100 ml extender).

The decrease of advanced motility of spermatozoa and the increase of dead spermatozoa abnormality sperm. These results by elevating storage temperature or incubation time are in agreement with those of Matsuoka et al.(2006) who reported that cryopreservation induces partially irreversible damage to sperm membranes, which may decrease sperm motility, viability 
and the fertilization rate after artificial insemination. Damage during cryopreservation has been attributed to oxidative stress, cryoprotectant toxicity, osmotic changes and lipidprotein reorganizations within the cell membranes (Purdy et al., 2005).

Collectively, increasing total free amino acids due to supplementation with gelatin and $\alpha$ - chemotrypsin was associated with improved semen quality. Several mechanisms have been proposed for the roles of amino acids during cryopreservation. Oltjen et al. (1971) showed that high amounts of total free amino acids are important for the semen quality and the fertility of the animals. Ibrahim and Boldizsár (1981) also noted that there is some evidence that the amino acids present in the seminal plasma play an important role in survival of spermatozoa. The function of seminal plasma free amino acids is shown to act as fuels for the spermatozoa, to create favorable conditions for cell survival and to be probably involved in detoxifying function. Kundu et al. (2001) suggested that the protective effects of amino acids may stem from their ability to form a layer on the spermatozoa surface, as these positively charged molecules can combine with the phosphate groups of sperm plasma membrane phospholipids. Also, Atessahin et al.( 2008) showed that addition of amino acids to extender improved sperm motility, viability, acrosomal integrity and membrane integrity in goat and boar. Moreover, cysteine has been shown to improve motility and morphology of ram (Uysal and Bucak, 2007) and goat sperm, (Buck et al., 2008) and to maintain the viability, the chromatin structure and membrane integrity of boar sperm (Sariozkan et al., 2009).

Likewise, Nagy et al. (2003) reported that gelatin addition to extender semen had a positive effect on preserved semen quality. They found a higher percentage of live cells in semen preserved with as compared to free gelatin. On the other hand, some investigators found no differences in goat and sheep semen motility when fresh semen extender was supplemented with gelatin immediately after semen collection (Salvador et al., 2006).

\section{Transaminase enzyme activities}

Tables 4 and 5 exhibit alanine - aminotransferase (ALT) and aspatateaminotransferase (AST) activities in seminal plasma being reduced $(\mathrm{P}<0.05)$ in treated than controls. As time of preservation progressed at either temperature, there exist significant increases $(\mathrm{P}<0.05)$ in the ALT and AST activities. However, as the storage temperature increased, there found significant decreases $(\mathrm{P}<0.05)$ ALT and AST activities. The lower release of these two metabolic enzymes in supplemented extenders could be attributed to the protective effects of free amino acids and peptides on the integrity of 
IMPACT OF GELATIN AND $\alpha$-CHYMOTRYPSIN SUPPLEMENTATION IN RABBITS 9

Table 4. Effect of gelatin and $\alpha$-chemotrypsin supplementation and incubation time at $37 \circ \mathrm{C}$ on seminal plasma activity of ALT and AST (LSM \pm SEM)

\begin{tabular}{|c|c|c|}
\hline \multirow{2}{*}{ Items } & \multicolumn{2}{|c|}{ Seminal plasma enzyme } \\
\hline & ALT (U/L) & AST (U/L) \\
\hline \multicolumn{3}{|c|}{ Effect of supplementation } \\
\hline $\mathrm{C}$ & $62.92 \pm 1.40^{\mathrm{a}}$ & $78.55 \pm 1.50^{\mathrm{a}}$ \\
\hline G0 & $59.25 \pm 0.82^{\mathrm{b}}$ & $72.77 \pm 0.85^{\mathrm{b}}$ \\
\hline G100 & $57.99 \pm 0.76^{\mathrm{b}}$ & $71.84 \pm 0.77^{\mathrm{b}}$ \\
\hline G200 & $57.59 \pm 0.67^{\mathrm{b}}$ & $71.04 \pm 0.82^{b}$ \\
\hline G400 & $57.66 \pm 0.66^{\mathrm{b}}$ & $71.11 \pm 0.79^{\mathrm{b}}$ \\
\hline \multicolumn{3}{|c|}{ Effect of incubation time $(h)$ at $37^{\circ} C$} \\
\hline 0 & $53.05 \pm 0.37^{\mathrm{c}}$ & $67.23 \pm 0.22^{c}$ \\
\hline 2 & $59.04 \pm 0.21^{\mathrm{b}}$ & $72.98 \pm 0.59^{\mathrm{b}}$ \\
\hline 4 & $64.45 \pm 0.45^{\mathrm{a}}$ & $78.79 \pm 0.68^{\mathrm{a}}$ \\
\hline \multicolumn{3}{|c|}{$\begin{array}{l}\text { Means in the same column within category with different superscripts significantly differ } \\
(\mathrm{P} \leq 0.05) . * \mathrm{C}=\text { Control, } \mathrm{G} 0=\mathrm{Gelatin}, \mathrm{G} 100=\text { Gelatin }+100 \mathrm{mg} \alpha \text {-Chemotrypsin, } \mathrm{G} 200=\text { Gelatin }+ \\
200 \mathrm{mg} \alpha \text {-Chemotrypsin, } \mathrm{G} 400=\text { Gelatin }+400 \mathrm{mg} \alpha \text {-Chemotrypsin }(/ 100 \mathrm{ml} \text { extender }) \text {. } \\
\text { ALT:Aspartate- aminotranseferase AST:Alanine }- \text { aminotranseferase. }\end{array}$} \\
\hline
\end{tabular}

Table 5. Effect of gelatin and $\alpha$-chemotrypsin supplementation and storage time at $5^{\circ} \mathrm{C}$ on ALT and ASTactivity (LSM \pm SEM)

\begin{tabular}{|c|c|c|}
\hline \multirow{2}{*}{ Items } & \multicolumn{2}{|c|}{ Seminal plasma enzyme } \\
\hline & $\operatorname{ALT}(\mathbf{U} / \mathbf{L})$ & $\operatorname{AST}(\mathbf{U} / \mathbf{L})$ \\
\hline \multicolumn{3}{|c|}{ Effect of supplementation } \\
\hline $\mathrm{C}$ & $77.62 \pm 1.12^{\mathrm{a}}$ & $104.64 \pm 3.44^{\mathrm{a}}$ \\
\hline G0 & $66.99 \pm 0.60^{\mathrm{b}}$ & $96.52 \pm 2.91^{\mathrm{b}}$ \\
\hline G100 & $65.18 \pm 0.59^{b}$ & $93.99 \pm 2.44^{\mathrm{b}}$ \\
\hline G200 & $64.33 \pm 0.52^{b}$ & $90.62 \pm 2.17^{b}$ \\
\hline G400 & $64.99 \pm 0.59^{\mathrm{b}}$ & $92.41 \pm 0.41^{\mathrm{b}}$ \\
\hline \multicolumn{3}{|c|}{ Effect of storage time (h) at $5^{\circ} \mathrm{C}$} \\
\hline 24 & $64.11 \pm 0.57^{\mathrm{c}}$ & $76.67 \pm 0.38^{\mathrm{c}}$ \\
\hline 48 & $68.20 \pm 0.71^{\mathrm{b}}$ & $101.93 \pm 0.63^{b}$ \\
\hline 72 & $72.37 \pm 0.96^{\mathrm{a}}$ & $110.11 \pm 1.33^{\mathrm{a}}$ \\
\hline
\end{tabular}

Means in the same column within a category with different superscripts significantly differ $(\mathrm{P} \leq 0.05)$ * $\mathrm{C}=$ Control, $\mathrm{G} 0=$ Gelatin, G100 $=$ Gelatin $+100 \mathrm{mg} \alpha$-Chemotrypsin, G200= Gelatin $+200 \mathrm{mg} \alpha-$ Chemotrypsin, G400= Gelatin $+400 \mathrm{mg} \alpha$-Chemotrypsin (/100 ml extender). ALT:Aspartateaminotranseferase AST:Alanine - aminotranseferase.

the sperm cell membranes. These observations are in agreement with that found in goat semen (Kundu et al., 2001). They concluded that addition of glutamine, glycine and cysteine in conventional storage medium improved membrane and acrosomal integrity of spermatozoa. However, Sariozkan et al. (2009) demonstrated that amino acid enhanced the defense of 
mammalian cell membrane and improved cell membrane integrity during sperm storage. Furthermore, change of biochemical factors have been recognized during cryopreservation, including depletion of amino acids and lipoproteins release of AST (Barbas and Mascarenhas, 2009). Moreover, Numan et al. (2010) showed that storage generates sublethal injury to the sperm due to chemical, osmotic, thermal, and mechanical stresses which may result in loss of viability, motility, damage of deoxyribonucleic acid (DNA) and destruction of plasma membrane, while amino acids supplementation have an important roles in preventing damage in animal's spermatozoa during crypreservation stage.

Seminal plasma antioxidants

Inclusion of gelatin and $\alpha$-chemotrypsin in the rabbit semen extender decreased $(\mathrm{P}<0.05)$ TBARS concentration and SOD activity, but $(\mathrm{P}<0.05)$ increased glutathione reduced (Table 6 and 7). Contrariwise, as time of incubation progressed, BARS and SOD in $(\mathrm{P}<0.05)$. Agarwal et al. (2007) mentioned that the sperm are susceptible to reactive oxygen species (ROS) attack. The imbalance between the production of ROS and a biological systems ability to readily detoxify the reactive intermediates or easily repair the resulting damage is known as oxidative stress (Agarwal et al., 2003). Oxidative stress is induced by ROS, or free radicals. However, ROS have been shown to be required for sperm capacitation, hyperactivation and sperm-oocyte fusion. Aitken et al. (2004) reported that excessive levels of ROS can negatively impact sperm quality. Since, increased levels of ROS have been correlated with decreased sperm motility; increased sperm DNA damage (Barroso et al., 2000), sperm cellular membrane lipid peroxidation and decreased efficacy of oocyte-sperm fusion (Agarwal et al., 2007).

Antioxidant capability in sperm cells is limited due to deficiency in cytoplasmic components having antioxidant effects to expunction of reactive oxygen. Thus, mammal's sperm have not enough ability to encountering with peroxidation during the storage (Alvarez and Storey, 2005). Moreover, Agrawal et al. (2005) demonstrated that antioxidants are the major defensive mechanism against oxidative stress. Reactive oxygen is responsible to sperm membrane damage and directly damage sperm DNA that cause reduction in the sperm motility, acrosomal integrity and sperm metabolic alterations.

Antioxidant capability in sperm cells is limited due to deficiency in cytoplasmic components having antioxidant effects to expunction of reactive oxygen. Thus, mammal's sperm have not enough ability to encountering with peroxidation during the storage (Alvarez and Storey, 2005). Moreover, Agrawal et al. (2005) demonstrated that antioxidants are the major defensive mechanism against oxidative stress. Reactive oxygen 
Table 6. Effect of gelatin and $\alpha$-chemotrypsin supplementation and incubation time at $37^{\circ} \mathrm{C}$ on TBARS, GSH and SOD $(\mathrm{LSM} \pm \mathrm{SEM})$

\begin{tabular}{|c|c|c|c|}
\hline \multirow[b]{2}{*}{ Items } & \multicolumn{3}{|c|}{ Metabolite } \\
\hline & $\begin{array}{l}\text { TBARS } \\
(\mathrm{nmol} / \mathrm{ml})\end{array}$ & GSH (mg/dl) & SOD (IU) \\
\hline \multicolumn{4}{|c|}{ Effect of supplementation } \\
\hline $\mathrm{C}$ & $1.53 \pm 0.04^{\mathrm{a}}$ & $422.6 \pm 10.34^{\mathrm{d}}$ & $1.48 \pm 0.03^{\mathrm{a}}$ \\
\hline G0 & $1.48 \pm 0.03^{\mathrm{b}}$ & $440.46 \pm 7.53^{\mathrm{c}}$ & $1.44 \pm 0.03^{\mathrm{b}}$ \\
\hline G100 & $1.34 \pm 0.02^{\mathrm{c}}$ & $454.52 \pm 7.22^{\mathrm{b}}$ & $1.32 \pm 0.02^{\mathrm{d}}$ \\
\hline G200 & $1.29 \pm 0.02^{\mathrm{c}}$ & $453.96 \pm 7.82^{\mathrm{b}}$ & $1.36 \pm 0.03^{\mathrm{c}}$ \\
\hline G400 & $1.33 \pm 0.02^{\mathrm{c}}$ & $460.10 \pm 6.95^{\mathrm{a}}$ & $1.37 \pm 0.03^{\mathrm{c}}$ \\
\hline \multicolumn{4}{|c|}{ Effect of incubation time (h) at $37^{\circ} \mathrm{C}$} \\
\hline 0 & $1.23 \pm 0.02^{\mathrm{c}}$ & $505.14 \pm 1.39^{\mathrm{a}}$ & $1.24 \pm 0.01^{\mathrm{c}}$ \\
\hline 2 & $1.51 \pm 0.03^{\mathrm{a}}$ & $429.64 \pm 2.32^{b}$ & $1.49 \pm 0.02^{\mathrm{a}}$ \\
\hline 4 & $1.46 \pm 0.02^{\mathrm{b}}$ & $406.58 \pm 3.32^{c}$ & $1.45 \pm 0.02^{\mathrm{b}}$ \\
\hline
\end{tabular}

Table 7. Effect of gelatin and $\alpha$-chemotrypsin supplementation and storage time at $5^{\circ} \mathrm{C}$ on TBARS, GSH and SOD (LSM \pm SEM)

\begin{tabular}{|c|c|c|c|}
\hline \multirow[b]{2}{*}{ Items } & \multicolumn{3}{|c|}{ Metabolite } \\
\hline & $\begin{array}{l}\text { TBARS } \\
(\mathrm{nmol} / \mathrm{ml})\end{array}$ & GSH (mg/dl) & SOD(IU) \\
\hline \multicolumn{4}{|l|}{ Effect of supplementation } \\
\hline $\mathrm{C}$ & $1.67 \pm 0.05^{\mathrm{a}}$ & $422.10 \pm 7.74^{\mathrm{d}}$ & $1.42 \pm 0.03^{\mathrm{a}}$ \\
\hline G0 & $1.49 \pm 0.04^{\mathrm{b}}$ & $472.75 \pm 6.21^{\mathrm{b}}$ & $1.33 \pm 0.03^{\mathrm{b}}$ \\
\hline G100 & $1.41 \pm 0.03^{\mathrm{c}}$ & $479.32 \pm 7.11^{\mathrm{b}}$ & $1.29 \pm 0.02^{\mathrm{c}}$ \\
\hline G200 & $1.36 \pm 0.02^{\mathrm{cd}}$ & $507.59 \pm 3.25^{\mathrm{a}}$ & $1.27 \pm 0.03^{\mathrm{c}}$ \\
\hline G400 & $1.38 \pm 0.03^{\mathrm{c}}$ & $494.94 \pm 5.49^{\mathrm{a}}$ & $1.28 \pm 0.03^{\mathrm{c}}$ \\
\hline \multicolumn{4}{|c|}{ Effect of storage time (h) at $5^{\circ} \mathrm{C}$} \\
\hline 24 & $1.24 \pm 0.02^{\mathrm{c}}$ & $506.77 \pm 3.61^{\mathrm{a}}$ & $1.16 \pm 0.01^{\mathrm{c}}$ \\
\hline 48 & $1.52 \pm 0.02^{\mathrm{b}}$ & $481.86 \pm 3.86^{\mathrm{b}}$ & $1.40 \pm 0.02^{\mathrm{a}}$ \\
\hline 72 & $1.61 \pm 0.03^{\mathrm{a}}$ & $431.38 \pm 5.80^{\mathrm{c}}$ & $1.36 \pm 0.02^{\mathrm{b}}$ \\
\hline
\end{tabular}

Means in the same column within category with different superscripts significantly $(\mathrm{P}<0.05)$ differ. * $\mathrm{C}=$ Control, G0= Gelatin, G100= Gelatin $+100 \mathrm{mg} \alpha$-Chemotrypsin, G200 $=$ Gelatin $+200 \mathrm{mg} \alpha$ Chemotrypsin, G400= Gelatin $+400 \mathrm{mg} \alpha$-Chemotrypsin (/100 ml extender). TBARS: Thiobarbituric acid-reactive substances GSH: Glutathione SOD: Superoxide dismutase

is responsible to sperm membrane damage and directly damage sperm DNA that cause reduction in the sperm motility, acrosomal integrity and sperm metabolic alterations. These findings are similar to results obtained 
by Scanchez-Partidata et al. (1992) who creased and GSH decreased demonstrated that the addition of low concentration of proline and betaine glycine (a component related to amino acids) to a medium containing egg yolk and glycerol improved the motility of ram spermatozoa. Buck et al. (2008) showed a positive effect of cysteine on motility and membrane integrity. Raji et al. (2003) reported that low sperm motility and high percentage of abnormal spermatozoa level have been associated with fertility reduction. Sariozkan et al. (2009) also demonstrated that cysteine is one of the additives that have been used in freezing extender of human, boar, goat and bull to improve post-thaw sperm parameters. Addition of cysteine and lipoic acid to the semen freezing extender, may prevent cryodamage to spermatozoa metabolism and antioxidant capacities (Rahim Beheshti et al., 2011).

\section{Reproductive Performance}

Table 8 indicates that kindling rate of females artificially inseminated with semen extender supplemented with gelatin and different levels of $\alpha$ chemotrypsin was improved compared with the control group. In addition, the total and live litter size at birth, litter size at weaning, bunny weights at birth and at 28 days were higher for groups of $\alpha$-chemotrypsin and gelatin

Table 8. Effect of supplementation of the rabbit semen extender with gelatin and $\alpha$-chemotrypsin on subsequent reproductive performance $(\mathrm{LSM} \pm \mathrm{SEM})$

\begin{tabular}{|c|c|c|c|c|c|}
\hline \multirow{2}{*}{ Items } & \multicolumn{5}{|c|}{ Gelatin $(1 \mathrm{~g} / 100 \mathrm{ml})+\alpha$-chemotrypsin $(\mathrm{mg} / 100 \mathrm{ml})$} \\
\hline & Control & G0 & G 100 & G 200 & G 400 \\
\hline Kindling rate $(\%)$ & $55.70 \pm 0.75^{\mathrm{c}}$ & $66.30 \pm 0.69^{\mathrm{b}}$ & $79.70^{\mathrm{a}} \pm 0.96^{\mathrm{a}}$ & $85.80 \pm 0.87^{\mathrm{a}}$ & $81.30 \pm 0.83^{\mathrm{a}}$ \\
\hline Litter size at birth (n.) & $5.38 \pm 0.54^{\mathrm{c}}$ & $7.13 \pm 0.63^{\mathrm{b}}$ & $7.03^{\mathrm{b}} \pm 0.58^{\mathrm{b}}$ & $10.41 \pm 0.60^{\mathrm{a}}$ & $9.87 \pm 0.57 \mathrm{a}$ \\
\hline Live litter size at birth (n.) & $4.56 \pm 0.53^{c}$ & $6.42 \pm 0.65^{\mathrm{b}}$ & $6.63^{\mathrm{b}} \pm 0.66^{\mathrm{b}}$ & $9.00 \pm 0.57^{\mathrm{a}}$ & $8.61 \pm 0.62^{\mathrm{a}}$ \\
\hline Litter size at weaning (n.) & $4.10 \pm 0.49^{\mathrm{c}}$ & $6.22^{\mathrm{b}} \pm 0.58^{\mathrm{b}}$ & $6.36^{\mathrm{b}} \pm 0.46^{\mathrm{b}}$ & $8.07 \pm 0.51^{\mathrm{a}}$ & $7.87 \pm 0.63^{\mathrm{a}}$ \\
\hline Bunny weight at birth (g) & $44.90 \pm 0.82^{\mathrm{c}}$ & $53.50 \pm 0.93^{\mathrm{b}}$ & $55.20^{\mathrm{b}} \pm 0.81^{\mathrm{b}}$ & $68.20 \pm 0.73^{\mathrm{a}}$ & $65.20 \pm 091^{\mathrm{a}}$ \\
\hline Bunny weight at 28 days (g) & $417.90 \pm 9.8^{\mathrm{c}}$ & $560.20 \pm 7.6^{\mathrm{b}}$ & $569.20^{\mathrm{b}} \pm 8.40^{\mathrm{b}}$ & $686.50 \pm 9.1^{\mathrm{a}}$ & $709.60 \pm 8.20^{\mathrm{a}}$ \\
\hline
\end{tabular}

than those of the control group. The levels of 200 and $400 \mathrm{mg} / 100 \mathrm{ml}$ with gelatin represented the same significant differences with other experimental $\alpha$-chemotrypsin levels and control. The improvement of the previous mentioned parameters of rabbit reproductive performance is due to the enrichment of semen extender with $\alpha$-chemotrypsin and gelatin which reflected on semen characteristics enhancement. The positive effect of 
amino acid and $\alpha$-chemotrypsin as an enhancer of reproductive capacity of rabbit bucks could be attributed to its ability to protect mammal cells from oxidation (Alvarez and Storey, 2005). Brun et al. (2002) found that sperm motility significantly $(\mathrm{P}<0.05)$ influenced the kindling rate. Furthermore, the same authors found that litter size (total born) was significantly influenced by motility and normal sperm. Katsoff et al. (1995) demonstrated that the use of $\alpha$ - chymotrypsin treatment of sperm bound with autoantibody was improve both fertilization and pregnancy rates following conventional insemination of oocytes.

In conclusion, rabbit semen extender supplementing with gelatin and $\alpha$ - chemotrypsin not only enhanced the semen quality and extended its storagability but it also improved its subsequent impacts on the reproductive performance.

\section{REFRENCES}

Adams, C. E., 1981. Artificial insemination in the rabbit: The technique and application to practice. Journal of Applied Rabbit Research, 4:10-13.

Agrawal, N.; Dasaradhi, P.V.N.; Mohmmed, A.; Malhotra, P.; Bhatnagar, R.K. and Mukherjee, S.K., (2003). RNA interference: biology, mechanism, and applications. Microbiol. Mol. Biol. Rev., 67: 657-685.

Agarwal, N.; Semmens, M.J.; Novak, P.J. and Hozalski, R.M., (2005). Zone of influence of a gas permeable membrane system for delivery of gases to groundwater. Water Resources Research, 41: ISSN: 0043-1397.

Agarwal, A, Prabhakaran, S.A, Sikka, S.C., (2007). Clinical relevance of oxidative stress in patients with male factor infertility: Evidence-based analysis. AUA Update Ser., 26: 1-12.

Aitken, R.J.; Ryan, A.L.; Baker, M.A.; McLaughlin, E.A., (2004). Redox activity associated with the maturation and capacitation of mammalian spermatozoa. Free Radic. Biol. Med.; 36: 994-1010.

Ali Al Ahmad, M. Z.; Chatagnon, G.; Amirat-Briand, L.; Moussa, M.; Tainturier, D.; Anton, M. and Fieni, F., (2008). Use of glutamine and low density lipoproteins isolated from egg yolk to improve buck semen freezing. Reprod. Domestic Anim., 43:429-436.

Alvarez, J.G. and Storey, B., (2005). Differential incorporation of fatty acids into and peroxidative loss of fatty acids from phospholipids of human spermatozoa. Mol. Reprod. Dev., 42 (3): 334-346. 
Atessahin, A.; Bucak, M.N.; Tuncer, P.B. and Kizil, M., (2008). Effects of antioxidant additives on microscopic and oxidative parameters of Angora goat semen following the freeze-thawing process. Small Ruminant Research, 77: 38-44.

Barbas J.P. and Mascarenhas R.D., (2009). Cryopreservation of domestic animal sperm cells. Cell Tissue Bank., 10: 49-62. doi: 10.1007/s10561008-9081-4

Barroso, G.; Morshedi, M.; Oehninger, S., (2000). Analysis of DNA fragmentation, plasma membrane translocation of phosphatidylserine and oxidative stress in human spermatozoa. Hum. Reprod., 15: 1338-1344.

Beutler, E.; Duron, O. and Kelly, B.M., (1963). Improved method for the determination of blood glutathione. J. Lab. and Clin. Med., 61:882-888.

Bilodeau, G.J.; Pelletier, G.; Pelletier, F.; Lévesque, C. A. and Hamelin, R. C., (2009). Multiplex real-time polymerase chain reaction (PCR) for detection of Phytophthora ramorum, the causal agent of sudden oak death. Can. J. Plant. Pathol., 31(2): 195-210.

Bollendorf, A.; Check, J.H.; Katsoff, D. and Fedele, A., (1994). The use of of chymotrypsin/galactose to treat spermatozoa bound with antisperm antibodies prior to intra/uterine insemination. Hum. Reprod., 9: 484-488.

Bronson, R.A.; Cooper, G.W.; Rosenfeld, D.L.; Gilbert, J.V. and Plaut, A.G., (1987). The effect of an IgA1 protease on immunoglobulins bound to the sperm surface and sperm cervical mucus penetrating ability. Fertil. Steril., 47: 985.

Brun, J.M.; Theau-Clément, M. and Bolet, G., (2002). The relationship between rabbit semen characteristics and reproductive performance after artificial insemination. Animal Reproduction Science, 70: 139-149.

Buck, M.N.; Atessahin, N. and Yuce, A., 2008. Effect of anti-oxidants and oxidative stress parameters of ram semen after the freeze-thawing process. Small Rum. Res., 75:128-134.

Centenaro, G.S.; Mellado, M.S. and Prentice-Hernández, C., (2011). Antioxidant Activity of Protein Hydrolysates of Fish and Chicken Bones. Advance Journal of Food Science and Technology, 3: 280-288.

Curry, M. R.; Millar, J. D. and Watson, P. F., (1994). Calculated optimal cooling rates for ram and human sperm cryopreservation fail to confirm with empirical observations. Biol. Reprod., 51:1014-1021.

Duncan, D. B. (1955. Multiple range and multiple F tests. Biometrics, 11:1-42.

Faithong, N.; Benjakul, S.; Phatcharat, S. and Binson, W., (2010). Chemical composition and antiocidative activity of Thai traditional fermented shrimp and krill products. Food Chemistry, 119: 133-140. 
Gadella, B. M.; Rathi, R.; Brouwers, J. F. H. M.; Stout, T. A. E. and Colenbrander, B., (2001). Capacitation and the acrosome reaction in equine sperm. Anim. Reprod. Sci., 68:249-265.

Gassner, F.X. and Hopwood, M.L., (1952). Seminal amino acid and carbohydrate pattern of bulls with normal and abnormal testes function. Proc. Soc. Exp. Biol. Medical., 81: 37-43.

Hamilton, P.B., (1962). Ion exchange chromatography of amino acidsmicrodetermination of free amino acids in serum. N. Y. Academy Sci. Ann., 102:55.

Ibrahim, M. A. and. Boldizsár, H., (1981). Studies on free amino acid content in seminal plasma of I. A. bulls of different performance. Acta Vet. Acad. Sci. Hung., 29: 263-269.

IRRG (2005). International Rabbit Reproduction Group. Recommendations and guidelines for applied reproduction trials with rabbit does. World Rabbit Sci., 13: 147-164.

Ka, H.H.; Sawai, K.; Wang, W.H.; Im, K.S. and Niwa, K., (1997). Amino acids in maturation medium and presence of cumulus cells at fertilization promote male pronuclear formation in porcine oocytes matured and penetrated in vitro. Biol Reprod., 57: 1483-1487.

Katsoff, D.; Check, J.H.; Bollendorf, A. and Benfer, K., (1995). Chymotrypsingalactose treatment of sperm with antisperm antibodies results in improved pregnancy rates following in vitro fertilization. Am. J. Reprod. Immunol., 33: 149-154.

Kim, S.C. and Kim, H.W. (1998). Effects of nitrogenous components of urine on sperm motility: an in vitro study. Int. J. Androl., 57: 1483-14878.

Kundu, C. N.; Das, K. and Majumder, G. C., (2001). Effect of amino acids on cauda epididymal sperm cryopreservation using a chemically defined model system. Cryobiology, 41:21-27.

Kutteh, W.H., (1996). Antiphospholipid antibody-associated recurrent pregnancy loss: treatment with heparin and low-dose aspirin is superior to low-dose aspirin alone. Am. J. Obstet. Gynecol., 174: 1584-1589.

Lopez e, F.J. and Alvarino, J.M.R., (2000). Effects of added caffeine on results following artificial insemination with fresh and refrigerated rabbit semen. Anim. Reprod., 58(1-2): 147-154

Lòpez-Gatius F.; Sances, G.; Sancho, M.; Yániz, J.; Santolaria, P. and Gutie'rrez, R., (2005). Effect of solid storage at $15^{\circ} \mathrm{C}$ on subsequent motility and fertility of rabbit semen. Theriogenology, 64:252-260. 
Matsuoka, S.; Iijima, M.; Watanabe, T. M.; Kuwayama, H.; Yanagida, T.; Devreotes, P. N. and Ueda, M., (2006). Single-molecule analysis of chemoattractant-stimulated membrane recruitment of a PH-domaincontaining protein. J. Cell Sci. , 119, 1071-1079.

Mazumdar, S. and Levine, A.S., (1998). Antisperm antibodies: etiology, pathogenesis, diagnosis, and treatment. Fertil. Steril., 70: 799-810.

Misra, H.P. and Fridovich, I., (1972). The role of superoxide anion in the autoxidation of epinephrine and a simple assay for superoxide dismutase. J. Biol. Chem., 247:3170-3175.

Nagy, A.; Gertsenstein, M.; Vintersten, K. and Behringer, R., (2003). In manipulating the mouse embryo: A laboratory manual, Isolation and culture of blastocyst-derived stem cell lines, ed Nagy A, et al. (Cold Spring Harbor Laboratory Press, Cold Spring Harbor, NY), 3rd ed, pp 359-370.

Numan,B. M.; Sarıözkan, S.; Sakin, F.; Yeni, D.; Cigerci, I.H.; Ateşşahin, A.; Avdatek, F.; Gundogan, M. and Buyukleblebici. O., (2010). The effect of raffinose and methionine on frozen/thawed Angora buck (Capra hircus ancryrensis) semen quality, lipid eroxidation and antioxidant enzyme activities. Cryobiology, 61: 89-93.

Oltjen, R.R.; Bond, J. and Gerrits, R.J., (1971). Growth and reproductive performance of bulls and heifers fed purified and natural diets. V. Free amino acid in the semen and blood plasma of bulls (puberty to 148 weeks of age). J. Anim. Sci., 33:814-818.

Purdy, P. H.; Fox, M. H. and Graham, J. K., (2005). The fluidity of Chinese hamster ovary cell and bull sperm membranes after cholesterol addition. Cryobiology, 51:102-112.

Rahim, Beheshti., Aiden , Asadi., Behrad, Eshratkhah., Jamshid , Ghiasi GhaleKandi., Abolfazl, Ghorbani, (2011). The Effect of Cysteine on Post-thawed Buffalo Bull (Bubalus Bubalis) Sperm Parameters Advances in Environmental Biology, 5(6): 1260-1263.

Raji, Y.; Udoh, U.S.; Mewoyaka, O.O.; Ononye, F.C. and Bolarinwa, A.F., (2003). Implication of reproductive endocrine malfunction in male antifertility efficacy of Azadirachta indica extract in rats. Afri. J. Med. Med. Sci., 32:159-165.

Reitman, S. and M. Frankel, (1957). An colorimetric method for determination of serum oxaloactic and glutamic pyruvic transaminase. Animal Clinical Pathology Journal, 16: 28-56

Rossini, P.M.; Rossi, S.; Babiloni, C. and Polich, J., (2007). Clinica neurophysiology of ging brain: from normal aging to neurodegeneration. Prog Neurobiol, 83:375-400. 
Roth, E.; Ollenschlager, G. and Hamilton, G., (1988). Influence of two glutamine-containing dipeptides on growth of mammalian cells. In Vitro Cell. Dev Biol., 21: 29-33.

Salvador I., Yániz J., Viudes de Castro M.P., Gómez E.A., Silvestre M.A., (2006). Effect of solid storage on caprine semen conservation at $5^{\circ} \mathrm{C}$. Theriogenology, 66: 974-981.

Sariozkan, S.; Bucak, M.N.; Tuncer, P.B.; Ulutas, P.A. and Bilgen. A., (2009). The influence of Taurine on microscopic oxidative stress parameters and fertilizing ability of bull semen following cryopreservation. Cryobiology, 58 (2): 134-138.

SAS, (2002). SAS/STAT User's Guide Statistics. SAS institute INC., Cary. NC, USA.

Scanchez-Partidata, L. G.; Maxwell, W. M. C.; Paleg, L. G. and Setchell, B. P., (1992). Proline and glycine betaine in cryoprotective diluents for ram spermatozoa. Reprod. Fertil. Dev., 4:113-118.

Sinha, M. P.; Sinha, A. K.; Singh, B. K. and Prasad, P. L., (1996). The effect of glutathione on the motility, enzyme leakage and fertility of frozen goat semen. Theriogenology, 41:237-243.

Spackman, D.H.; Stein, E.H. and Moore, S., (1958). Automatic recording apparatus for use in the chromatography of amino acids. Anal. Chem, 30: 1191.

Tappel, A.L. and Zalkin, H., (1959). Inhibition of lipid peroxidation in mitochondria by vitamin E. Archives of Biochemistry and Biophysics, 80: $333-336$.

Uysal, O. and Bucak, M.N., (2007). Effect of oxidized glutathione, bovine serum albumin, cysteine and lycopene on the quality of frozen thawed ram semen, Acta. Vet. Brno., 76:383-390.

WHO, World Health Organization. (1992). Laboratory Manual for the Examination of Human Semen and Sperm-cervical Mucus Interaction, 3rd ed. Cambridge: Cambridge University Press, 107 p.

Zaghloul, A.A., (2009). Effect of gelatin addition to extender on semen quality of rabbit. Egyptian Journal of Rabbit Science, 19 (1)1-6. 


\title{
تأثير أضافة الجيلاتين والالفاكيموتربسن في مخفف السائل المنوي

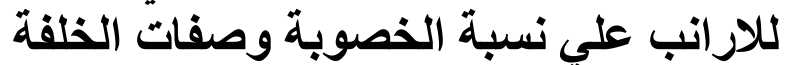

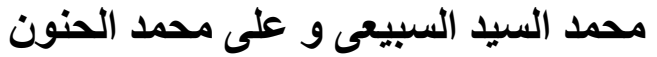 \\ معهد بحوث الاتناج الحيو انى ، مركز البحوث الزراعيه، مصر
}

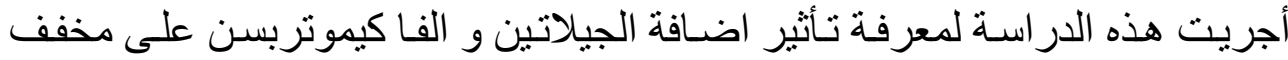

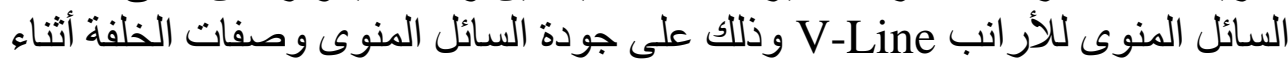

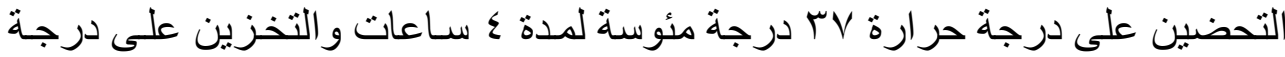

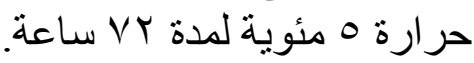

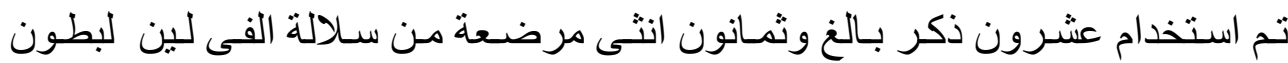

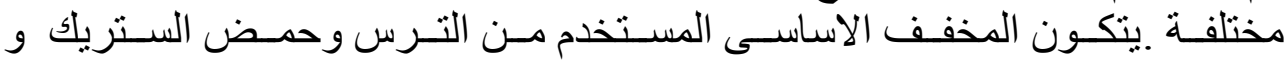

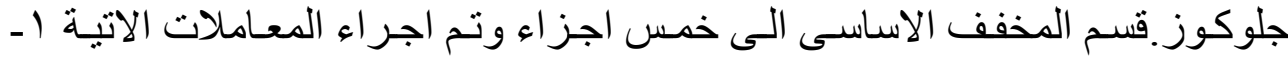

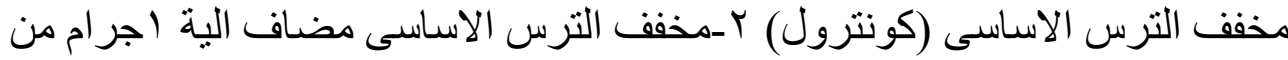

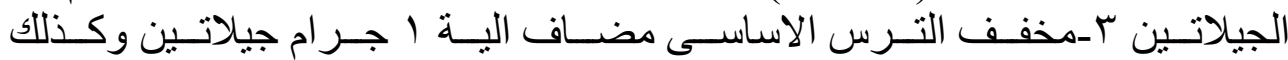

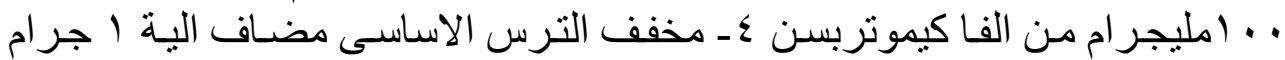

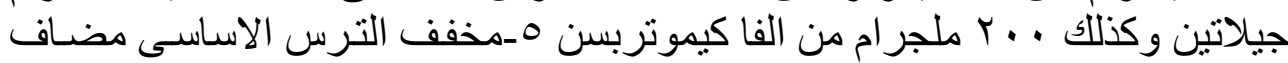

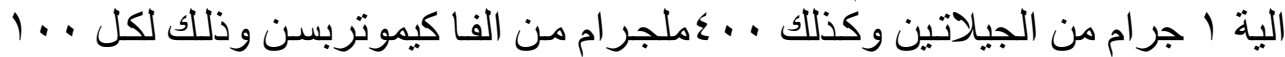

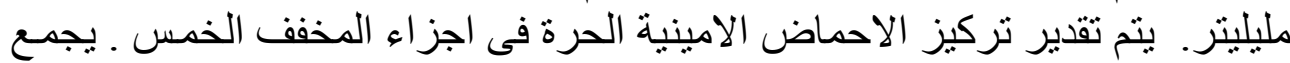

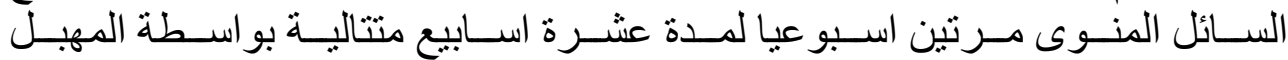

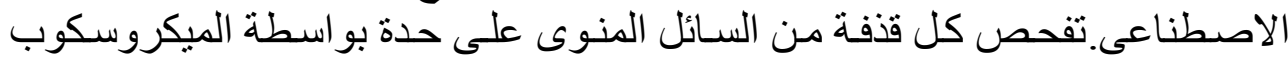

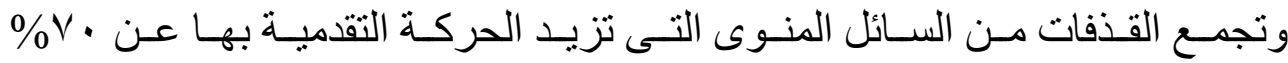

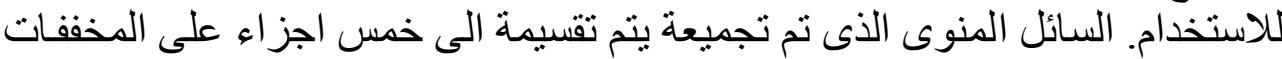

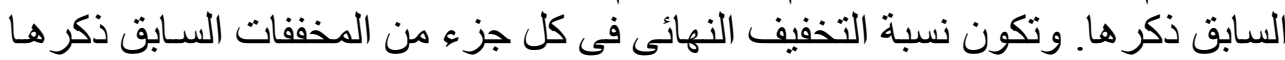

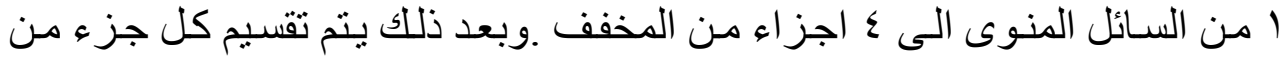

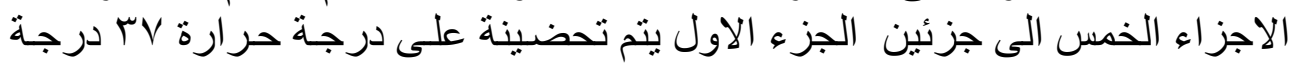

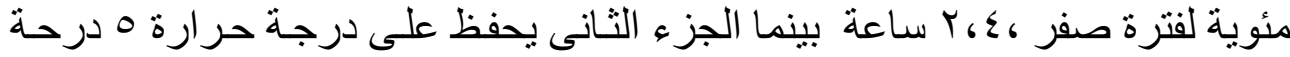

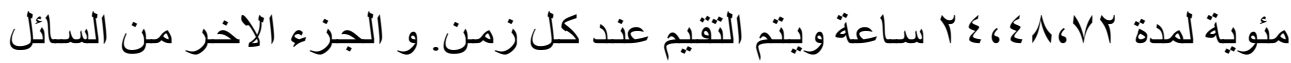

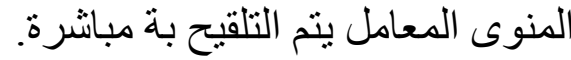

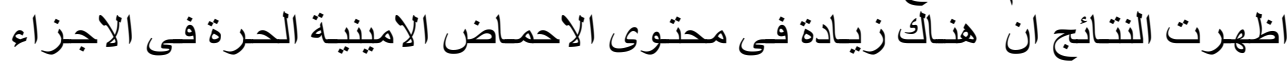

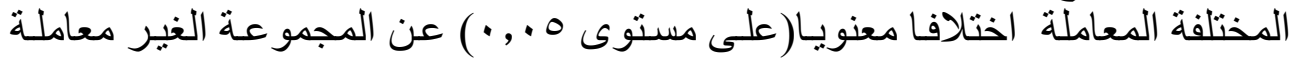

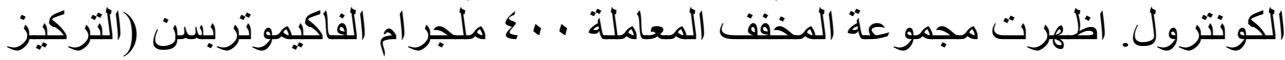
العالى) زيادة معنوية فى الاحمـاض الامينية و انخفاض معنوى (على مستوى 0. . , • ) 


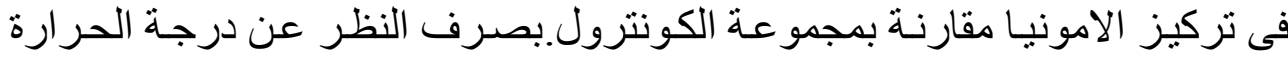

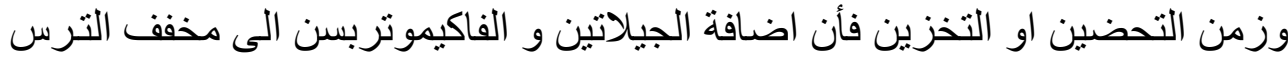

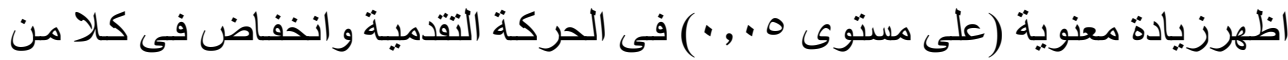

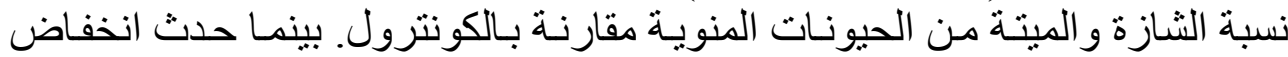

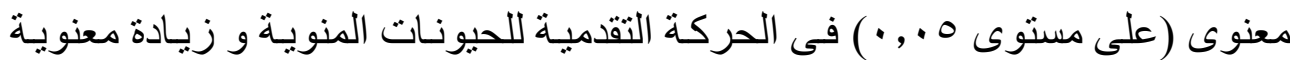

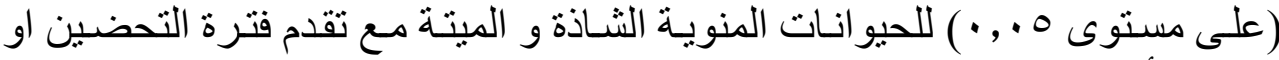

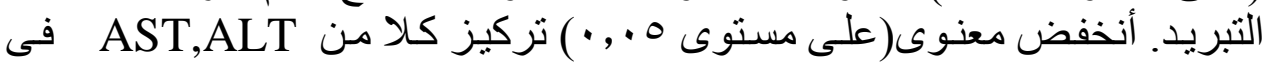

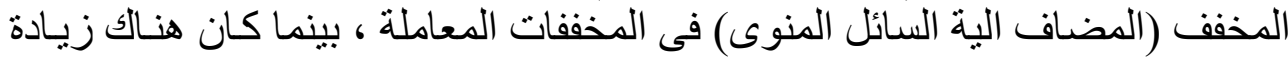

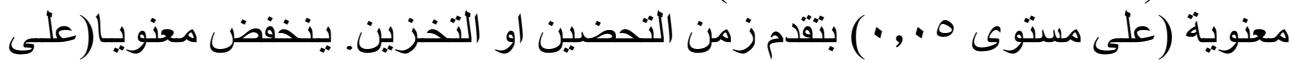

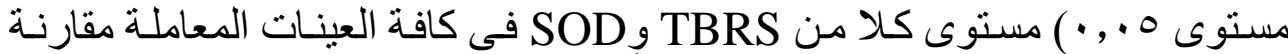

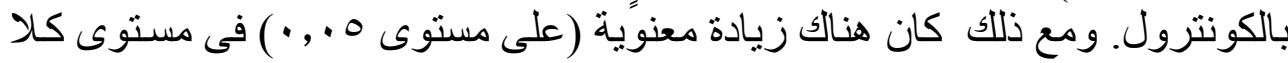

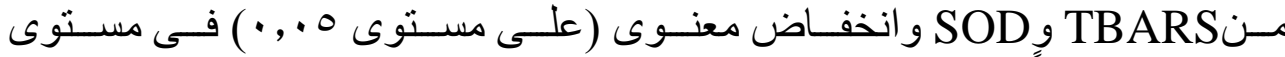

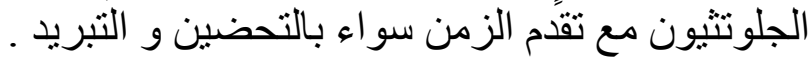

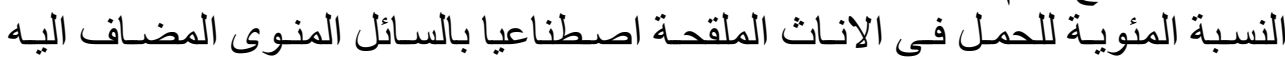

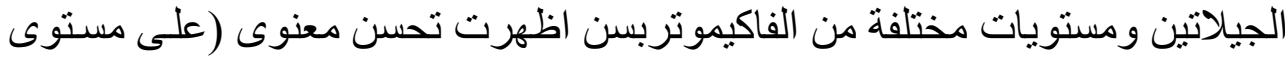

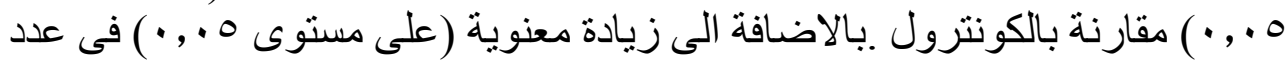

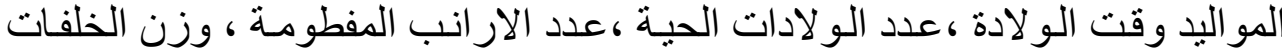

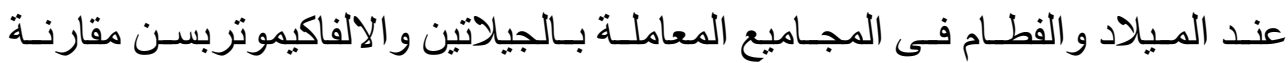

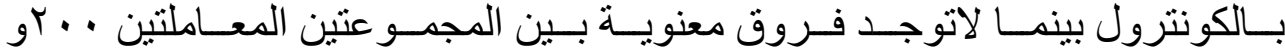
. . . علجر ام الفاكيموتربسن على هذه الصفات. 